\title{
Experimental evaluation of mechanical properties of friction welded mild steel
}

\author{
Eko Nugroho1, Eko Budiyanto ${ }^{*}$, Enggal Bagus Suseno ${ }^{3}$ \\ 1,2,3Prodi Teknik Mesin, Fakultas Teknik, Universitas Muhammadiyah Metro \\ Jl. Ki Hajar Dewantara 15 A Kota Metro, Lampung, Indonesia \\ ${ }^{*}$ Corresponding author: ekobudiyantoiyan@gmail.com
}

\begin{abstract}
Friction welding is a solid state joining process used to join similar and dissimilar metals, not possible with other available welding techniques. Now a day's Friction welding is most commonly used in industry that is aeronautical engineering, automobile engineering, submarine industry and heavy industry. In this research, an experimental setup was designed and fabricated in order to accomplish friction welded joints mild steel. Thereafter, the effect of forging pressures and rotation speed on the mechanical properties of friction welded ST 42 steels, produced by mechanical joining, have been investigated. Samples were welded under friction pressure $10 \mathrm{MPa}$ by different forging pressures $25 \mathrm{MPa}$ and $35 \mathrm{MPa}$ with different rotation speed $1095 \mathrm{rpm}, 1200 \mathrm{rpm}$, and $1400 \mathrm{rpm}$. The tensile strength values of the weldments were determined and evaluated. The top result is produced from sample were welded under forging pressures $35 \mathrm{MPa}$ at rotation speed $1400 \mathrm{rpm}$ that is tensile strength $437,27 \mathrm{~N} / \mathrm{mm}^{2}$ and yield strength $399,75 \mathrm{~N} / \mathrm{mm}^{2}$.
\end{abstract}

Keywords : friction welding, forging pressure, tensile strength, yield strength, and elongation.

\section{Introduction}

Steel is an important engineering material. It has found applications in many areas such as vehicle parts, truck, bed floors, automobile doors, domestic appliances, etc. It is capable of presenting economically a very wide range of mechanical and other properties. Traditionally mechanical components has been joined through fasteners, rivet joints etc. In other to reduce time for manufacturing, weight reduction and improvement in mechanical properties, welding process is usually adopted [1].

Friction welding is a solid state joining process used to join similar and dissimilar metals, not possible with other available welding techniques [2][3][4][5]. Now a day's Friction welding is most commonly used in industry that is aeronautical engineering, automobile engineering, submarine industry and heavy industry [3][6]. Friction welding method is one of the most simple, economical and highly productive method in joining dissimilar materials. It is widely used in the automotive, medical, and aerospace industrial applications [7].

Friction welding requires rapid rotation of one component at high rpm and other component is brought into contact at high forging pressure to get upset. Two pieces rotate in contact and heat necessary for welding is generated on friction plane [2]. The principle of this process is the changing of mechanical energy into heat energy. One work piece is rotated about its axis while the other work piece to be welded to it is stationary and does not rotate but can be moved axially to make contact with the rotating work piece. The rotation is stopped at the point of fusion and forging pressure is applied axially on to the stationary work piece. The hot work causes refinement of grain structure. Then welding is done, without melting of parent metal [4]. Considering the relative velocity and the friction motion between the interfaces, friction welding processes can be classified in two groups. The first group represents the various means where the heat is generated by the relative movement between the surfaces. The classical processes with 
rotary, linear, and orbital motion are representatives of this group.

Processes generating the friction due to a relative motion between a nonconsumable tool and the work piece surface can be classified as the second group. Friction Stir Welding (FSW) was developed by W.M. Thomas as a solid-state joining process which operates by way of a nonconsumable rotating tool with a specially designed pin and shoulder [8].

\section{Material and Methods}

\section{Material}

The material used in this experiment was mild steel (ST 42). All the specimens were made in cylindrical form having 15 $\mathrm{mm}$ diameter and $150 \mathrm{~mm}$ length. Tensile test specimens used ASTM E8 tandard as shown in Figures 1. A turning machine was used for friction welding process as shown in Figure 2. A specification turning machine was used for friction welding process as shown in Table 1.

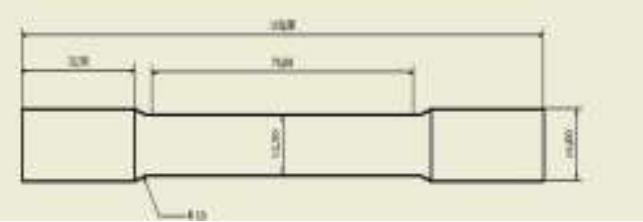

Figue 1. Tensile test specimen dimension

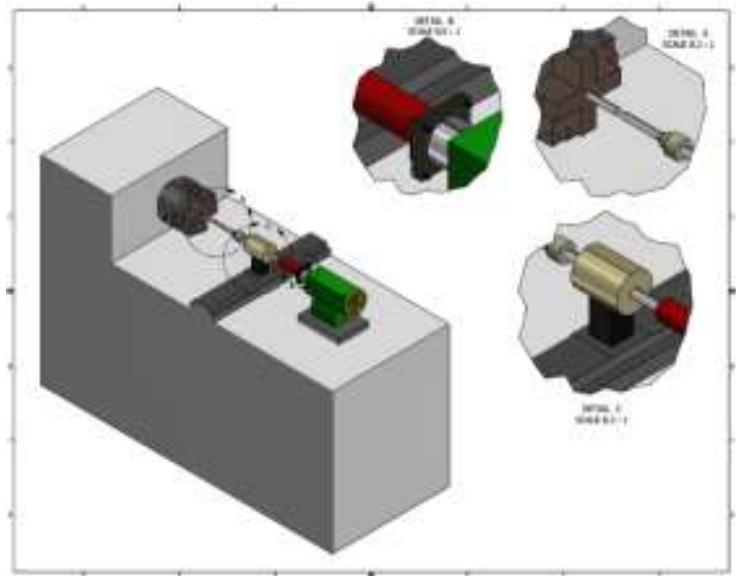

Figure 2. Scheme of friction welding process

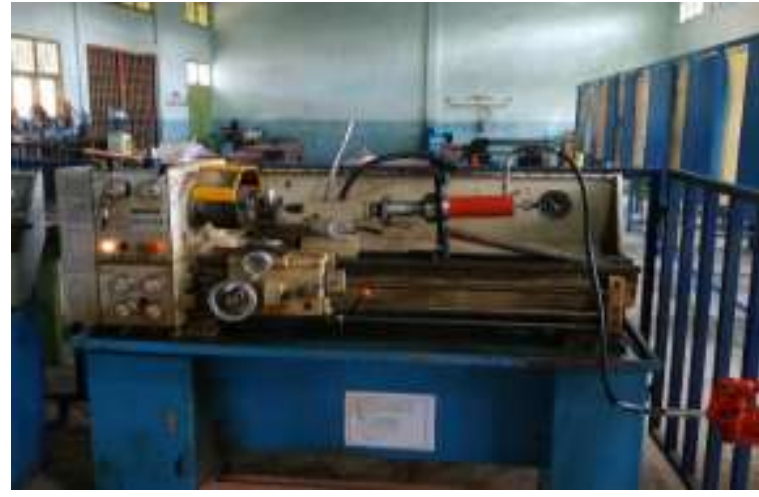

Figure 3. A turning machine was used for friction welding process

Table 1. Specification turning machine was used for friction welding

\begin{tabular}{l|l}
\hline Spindle Speed & $70-2000 \mathrm{rpm}$ \\
\hline Motor Spesifications & $\begin{array}{l}1,5 \mathrm{~kW}, 380 \mathrm{~V}, 3 \\
\mathrm{HP}\end{array}$ \\
\hline Dimenstion $(l \times w \times h)$ & $\begin{array}{l}177 \times 58 \times 127 \\
(\mathrm{~cm})\end{array}$ \\
\hline Weight & $655 \mathrm{~kg}$ \\
\hline
\end{tabular}

\section{Methods}

This experimental setup was designed and fabricated in order to accomplish friction welded joints mild steel. Thereafter, the effect of forging pressures and rotation speed on the mechanical properties of friction welded ST 42 steels, produced by mechanical joining, have been investigated. Samples were welded under friction pressure $10 \mathrm{MPa}$ by different forging pressures $25 \mathrm{MPa}$ and $35 \mathrm{MPa}$ with different friction speed (rotation speed) $1095 \mathrm{rpm}$, $1200 \mathrm{rpm}$, and $1400 \mathrm{rpm}$. The weldments will determine and evaluate by Ultimate Tensile Machine (UTM).

\section{Result and Discussion}

This research was conducted to determine the effect of forging pressure and rotation speed on the tensile strength of weldments of mild steel as a result of friction welding. After the friction welding process, the weldments are turned into tensile test specimens then a tensile test is carried out. The process of friction is approved in Figure 4. The tensile test results of friction welding specimens as shown in Figure 5. 


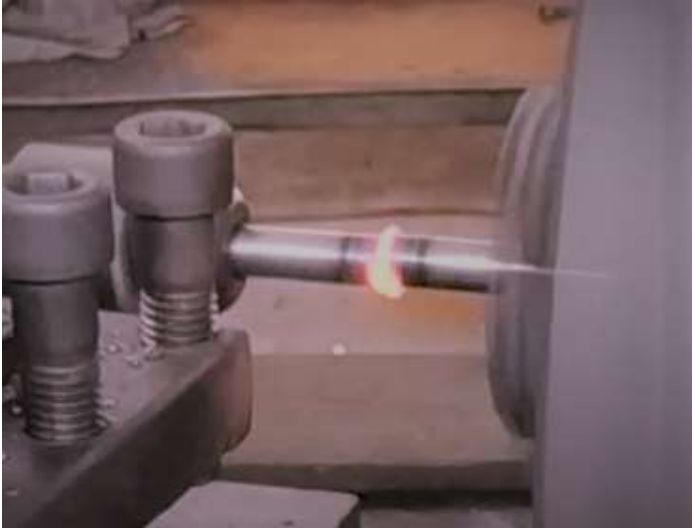

Figure 4. Friction welding processes
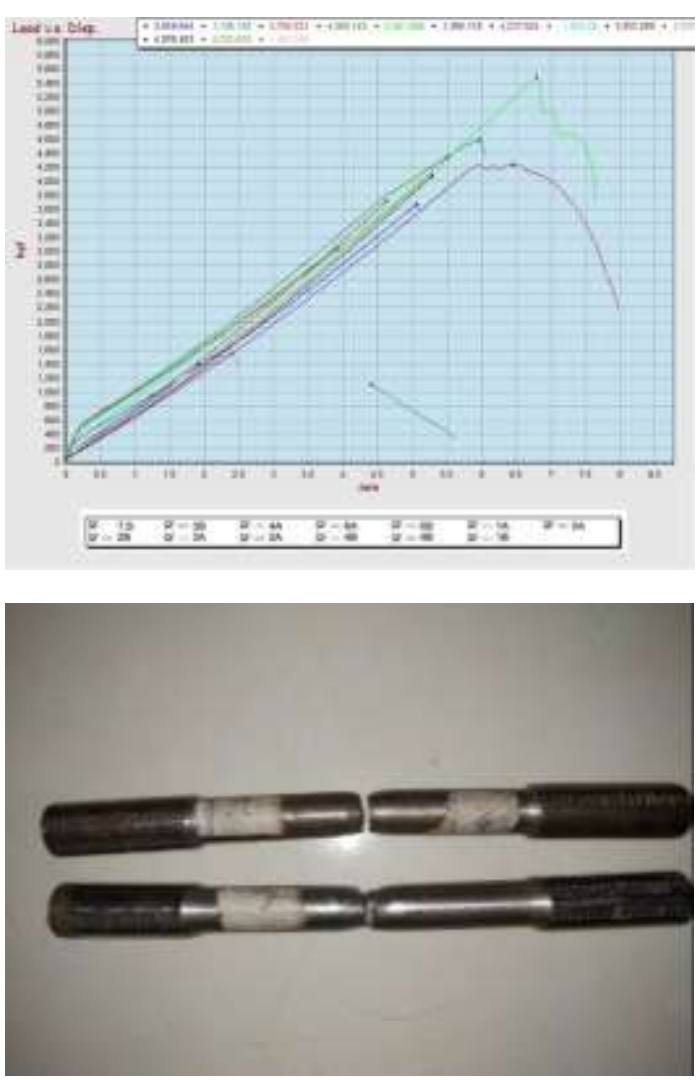

Figure 5. Diagram and specimens tensile test results

At friction welding under forging pressure $25 \mathrm{MPa}$, the tensile strength, yield strength, and elongation values are shown in Figure 6. And friction welding under forging pressure $35 \mathrm{MPa}$, the tensile strength, yield strength, and elongation values are shown in Figure 7.

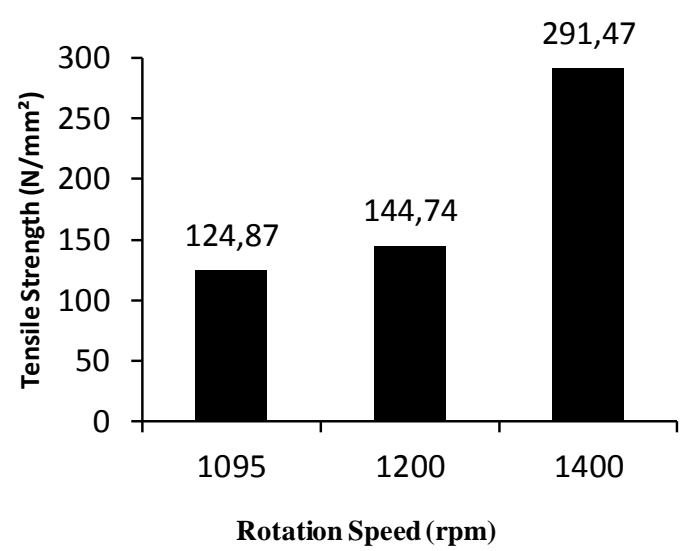

(a)

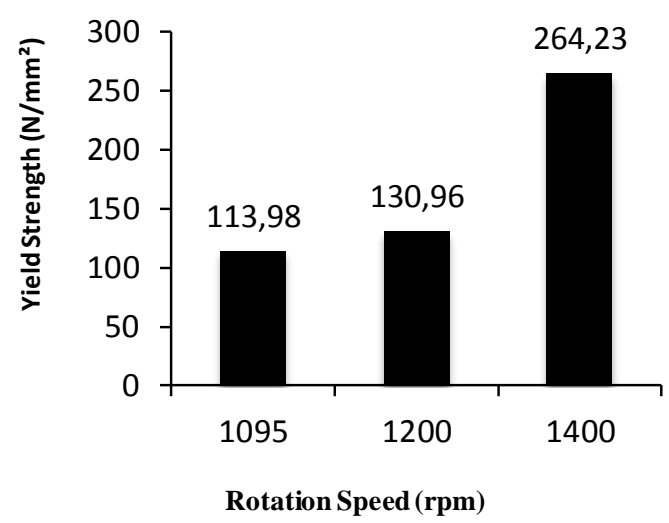

(b)

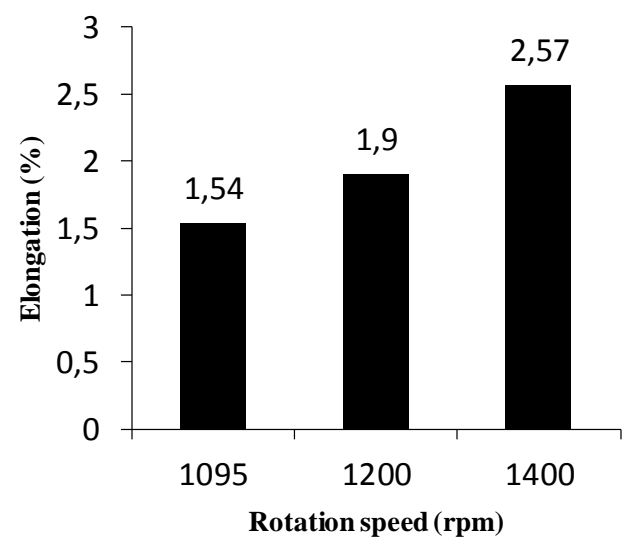

(c)

Figure 6. Mechanical properties UTS result of weldments under forging pressure $25 \mathrm{MPa}$. (a) Tensile Strength, (b) Yield Strength, (c) Elongation 


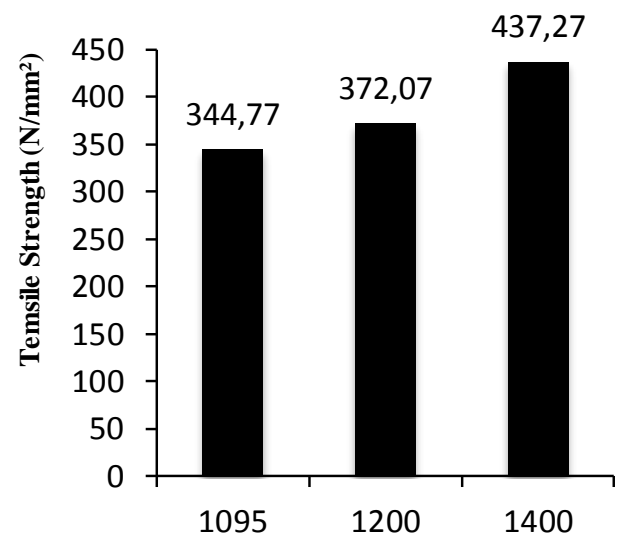

Rotation Speed (rpm)

(a)

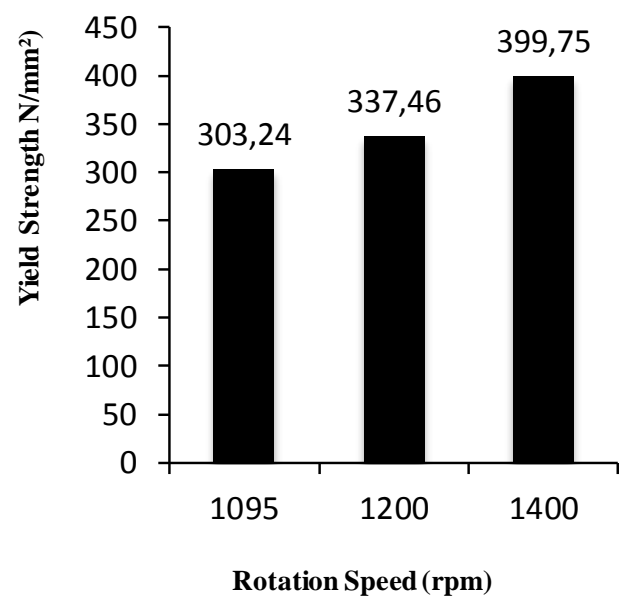

(b)

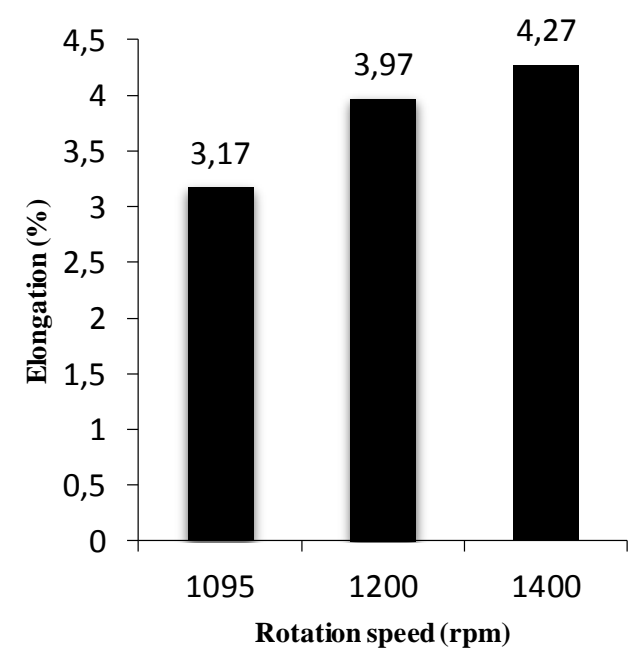

(c)

Figure 7. Mechanical properties UTS result of weldments under forging pressure $35 \mathrm{MPa}$. (a) Tensile Strength, (b) Yield Strength, (c) Elongation

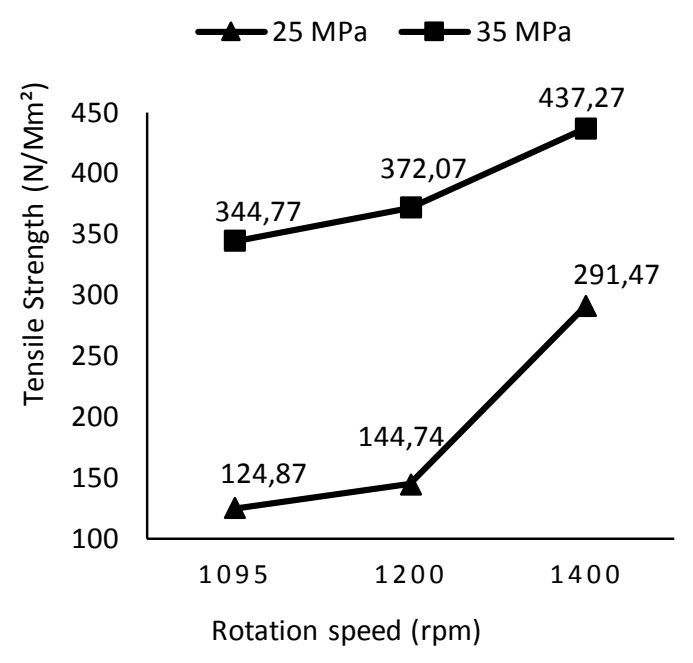

(a)

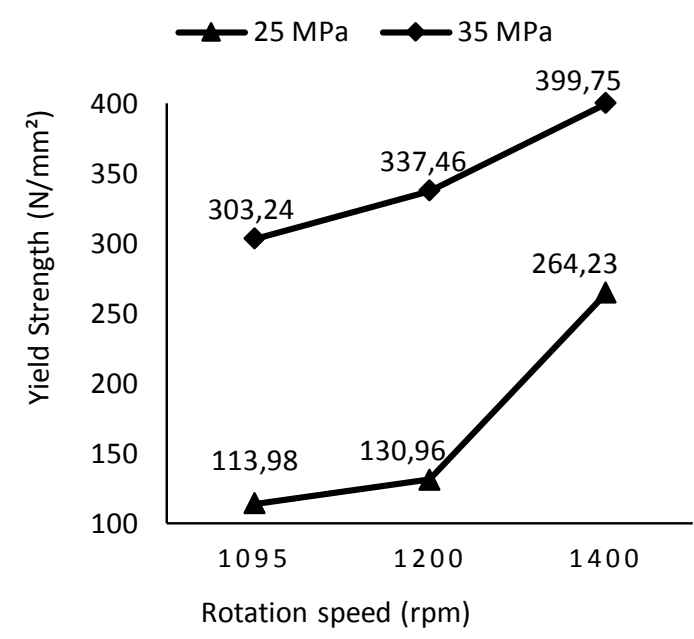

(b)

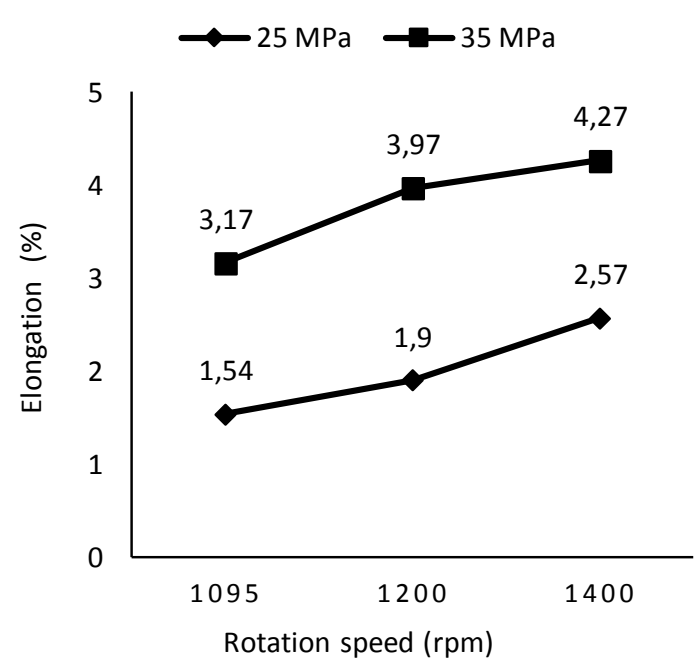

(c)

Figure 8. Comparasion mechanical properties of weldments under forging pressure $25 \mathrm{MPa}$ and 35 MPa. (a) Tensile Strength, (b) Yield Strength, (c) Elongation 
The top tensile strength value of the weldments under forging pressure $25 \mathrm{MPa}$ were determined at $291 \mathrm{~N} / \mathrm{mm}^{2}$ (rotation speed $1400 \mathrm{rpm}$ ), and the lowest tensile strength value of the weldments under forging pressure $25 \mathrm{MPa}$ were determined at $124,87 \mathrm{~N} / \mathrm{mm}^{2}$ (rotation speed $1095 \mathrm{rpm}$ ). Thereafter, the tensile strength value of the weldments under forging pressure $25 \mathrm{MPa}$ were determined at $144,74 \mathrm{~N} / \mathrm{mm}^{2}$ at rotation speed $1200 \mathrm{rpm}$. The top tensile strength value of the weldments under forging pressure $35 \mathrm{MPa}$ were determined at 437,27 N/mm (rotation speed $1400 \mathrm{rpm}$ ), and the lowest tensile strength value of the weldments under forging pressure $35 \mathrm{MPa}$ were determined at $344,77 \mathrm{~N} / \mathrm{mm}^{2}$ (rotation speed $1095 \mathrm{rpm})$. Thereafter, the tensile strength value of the weldments under forging pressure $35 \mathrm{MPa}$ were determined at $372,07 \mathrm{~N} / \mathrm{mm}^{2}$ at rotation speed $1200 \mathrm{rpm}$.

The top yield strength value of the weldments under forging pressure $25 \mathrm{MPa}$ were determined at $264,23 \mathrm{~N} / \mathrm{mm}^{2}$ (rotation speed $1400 \mathrm{rpm}$ ), and the lowest yield strength value of the weldments under forging pressure $25 \mathrm{MPa}$ were determined at $113,98 \mathrm{~N} / \mathrm{mm}^{2}$ (rotation speed $1095 \mathrm{rpm}$ ). Thereafter, the yield strength value of the weldments under forging pressure $25 \mathrm{MPa}$ were determined at $130,96 \mathrm{~N} / \mathrm{mm}^{2}$ at rotation speed $1200 \mathrm{rpm}$. The top yield strength value of the weldments under forging pressure $35 \mathrm{MPa}$ were determined at $399,75 \mathrm{~N} / \mathrm{mm}^{2}$ (rotation speed $1400 \mathrm{rpm}$ ), and the lowest yield strength value of the weldments under forging pressure $35 \mathrm{MPa}$ were determined at $303,24 \mathrm{~N} / \mathrm{mm}^{2}$ (rotation speed $1095 \mathrm{rpm})$. Thereafter, the yield strength value of the weldments under forging pressure $35 \mathrm{MPa}$ were determined at $337,46 \mathrm{~N} / \mathrm{mm}^{2}$ at rotation speed $1200 \mathrm{rpm}$.

The maximum elongation of the weldments under forging pressure $25 \mathrm{MPa}$ were determined at $2,57 \%$ (rotation speed $1400 \mathrm{rpm}$ ), and the minimum elongation of the weldments under forging pressure 25 $\mathrm{MPa}$ were determined at $1,54 \%$ (rotation speed $1095 \mathrm{rpm})$. Thereafter, the elongation of the weldments under forging pressure 25
MPa were determined at $1,9 \%$ at rotation speed $1200 \mathrm{rpm}$. The maximum elongation of the weldments under forging pressure 35 $\mathrm{MPa}$ were determined at 4,27\% (rotation speed $1400 \mathrm{rpm}$ ), and the minimum elongation of the weldments under forging pressure $35 \mathrm{MPa}$ were determined at 3,17\% (rotation speed $1095 \mathrm{rpm}$ ). Thereafter, the elongation of the weldments under forging pressure $35 \mathrm{MPa}$ were determined at 3,97\% at rotation speed $1200 \mathrm{rpm}$.

On the overal, the best material properties of the weldments under pressure $35 \mathrm{MPa}$ and rotation speed $1400 \mathrm{rpm}$, with maximum value of tensile strength 437,27 $\mathrm{N} / \mathrm{mm}^{2}$, maximum yield strength 399,75 , and maximum elongation 4,27 \% .

\section{Conclusion}

Friction welding has been successfully employed to weld mild steels. Strength of the joints also obtained was good. With the increase in forging pressure and rotation speed, the tensile strength increases. The maximum available tensile strength which was $437,27 \mathrm{~N} / \mathrm{mm}^{2}$, was available at pressure forging $35 \mathrm{MPa}$ and rotation speed $1400 \mathrm{rpm}$.

\section{Reference}

[1]. Talabi SI, Owolabi OB, Adebisi JA, Yahaya $T$. Effect of welding variables on mechanical properties of low carbon steel welded joint. Adv Prod Eng Manag. 2014;9(4):181-186. doi:10.14743/apem2014.4.186

[2]. Kumar S, Bhardwaj D, Sangwan J. A Research Paper on Temperature Modelling of Friction Welding of Aluminium and Stainless Steel-304. Int $J$ Enhanc Res Sci Technol Eng. 2014;3(6):319-327.

[3]. Kumar S, Kumar R, Singla YK. To Study the Mechanical Behaviour of Friction Welding of Aluminium Alloy. Int $J$ Mech Eng Robot Res. 2012;1(3):53-50.

[4]. Bhate SS, Bhatwadekar SG. a Literature Review of Research on Rotary Friction Welding. Int J Innov Technol Res. 
2016;4(1):2601-2604.

[5]. Ambroziak A, Korzeniowski M, Kustroń P, Winnicki M, Sokołowski P, Harapińska E. Friction welding of aluminium and aluminium alloys with steel. Adv Mater Sci Eng. 2014;2014. doi:10.1155/2014/981653

[6]. Handa A, Chawla V. Experimental evaluation of mechanical properties of friction welded AISI steels. Cogent Eng. 2014;1(1):1-10. doi:10.1080/23311916.2014.936996

[7]. Koushik PV, Avinash D. Experimental Investigations of Friction Welding Using Aluminum With Mild Steel. Int Res J Eng Technol. 2016;3(12):680685.

[8]. Besler FA, Schindele P, Grant RJ, Stegmüller MJR. Friction crush welding of aluminium, copper and steel sheetmetals with flanged edges. J Mater Process Technol. 2016;234:72-83. doi:10.1016/j.jmatprotec.2016.03.012 